\title{
Renewables as important energy source for Moldova
}

\author{
Mihai Stefan Tirsu* and Galina Nicolae Uzun
}

\begin{abstract}
The Republic of Moldova is dependent on energy imports in the proportion of 75 percent. This situation is also characteristic for many other countries. Under the circumstances, when a country lacks its own fossil energy sources, it needs to identify alternative solutions to reduce energy dependence and increase energy security. The Republic of Moldova is an agrarian country and has the possibility of growing biomass, and has many vegetal wastes, which could be used as bioenergy. Also, other renewable energy sources, such as wind and sun, are available in the territory and should be integrated into the energy circuit. The rapid development of bioenergy sources requires special programs, support schemes and other interventions by the authorities. The paper presents the solutions applied in the field of bioenergy by the decision-makers, the projects that have been carried out and the way of their implementation. It also presents the evolution of the situation in the bioenergy sector over the last 7 years and how dependence on energy imports has evolved as a result of the implementation of different mechanisms in this sector. Expected opportunities for further development of the sector and ways of accelerating the process of bioeconomy development are estimated. The solutions identified in the paper can be replicated in other countries, which are similar to the Republic of Moldova. On the other hand, each country has some targets for reducing greenhouse gas emissions. Moldova has ambitious targets that provide for a $65 \%$ reduction of CO2 emissions by 2030 compared to 1990 . The development of the bioenergy sector will contribute to an easier realization of these targets.
\end{abstract}

Keywords: renewable energy, biomass, biofuel, energy production, RES stimulation.

Institute of Power Engineering of Academy of Sciences of Moldova, Republic of Moldova

${ }^{*}$ Corresponding author: M.S. Tirsu E-mail: tirsu.mihai@gmail.com

DOI: 10.2478/ebtj-2018-0004

\section{Introduction}

Moldova is located in the south-eastern region of Europe and covers an area of approximately $34000 \mathrm{~km}^{2}$. The Moldova territory extends from north to south on a distance of $350 \mathrm{~km}$, from west to east - $150 \mathrm{~km}$. The land Fund of Moldova is 3384,6 thousand ha, including 2028,3 thousand ha with agricultural destination. The territory with agricultural destination has next distribution: $73,1 \%$ for plough lands, $11,5 \%$ for perennial plantations, $13,8 \%$ for hayfields and pastures and 1,6\% are plunge lands. The forest land covers 451 thousand ha. The black soils occupy $75 \%$ of the country's surface. The above mentioned futures of Moldova create good opportunities for energy generation from biomass and vegetal wastes.

Energy system of Moldova is the basis of its economy. Moldova finds itself in a complicated energy situation. This is because practically all energy resources are imported and their costs increase. Due to lack of own energy resources, the objective for the country's leadership is to securely supply Moldovan users with energy at affordable prices. In order to remain/become competitive, Moldovan companies need to have uninterrupted energy supplies and short-term predictable prices. At the same time, Moldova needs to diversify suppliers. This is achievable through participation in a number of regional energy projects and more active collaboration with the European Union. Considerably growing prices on energy resources demand a broader implementation of energy saving technologies and renewable energy sources (RES). 
Table 1. The specific energy parameters of crops with energy potential

\begin{tabular}{|l|c|c|c|c|c|}
\hline Plant varieties & Sugar, \% & $\begin{array}{c}\text { Yield, } \\
\text { t/ha }\end{array}$ & $\begin{array}{c}\text { Ethanol, } \\
\text { //ha }\end{array}$ & $\begin{array}{c}\text { Ethanol, } \\
\text { MJ/ha** }\end{array}$ & 7.065 \\
\hline Potato & 17.8 & 32.4 & 3693 & 79612 & 4.591 \\
\hline Sweet potato & 25 & 12 & 2400 & 51738 & 6.213 \\
\hline Root chicory & 16 & 35 & 3248 & 70019 & 5.460 \\
\hline Wheat & 62 & 7.2 & 2854 & 61526 & 4.113 \\
\hline Barley & 58 & 5.8 & 2150 & 46349 & 5.498 \\
\hline Maize & 65 & 6.9 & 2874 & 61957 & 5.460 \\
\hline Rye & 62 & 7.2 & 2854 & 61526 & 9.418 \\
\hline Fodder beet & 8.2 & 98.5 & 4923 & 106128 & 10.713 \\
\hline Sugar beet & 16 & 57.4 & 5600 & 120723 & 10.330 \\
\hline Sweet sorghum & 10 & 90 & 5400 & 116411 & 4.993 \\
\hline Topinambur & 15 & 30 & 2610 & 56265 & 5.460 \\
\hline Triticale & 62 & 7.2 & 2854 & 61526 & 6.887 \\
\hline Switchgrass & 60 & 20 & 3600 & 77607 & \\
\hline
\end{tabular}

The most suitable path to reduce country's energy import can be large involvement in energy circuit of such local energy sources like biomass, wastes from agriculture, municipalities, forest etc. Moldova during last 10 years started actively uses the biomass as energy resource. According to (9) in Moldova there are at list 25 species of annual and perennial cultures like shrubs, trees and herbaceous plants, which can be grown on large territory Moldova. The biomass of all these species can be involved in producing biofuel at industrial level. The energy potential was evaluated for all 25 species. In Table 1 it is shown the biofuel amounts yield from biomass treating as well as $\mathrm{CO}_{2}$ obtained after their burning.

One of the most strategically important options to increase share of global renewable energy market is to use biomass in energy circuit (1). But accelerated deployment of bioenergy resources can create conflicts related to land use, water resources and biodiversity conservation. From this point of view we need to raise a question if policies concerning bioenergy promotion are always justified. Moldova's authorities should elaborate right legislation in order to not affect bioenergy potential (2). Therefore, we need integrated policies for energy production, water management and land use. Also, it is necessary to take in consid- eration existing volume of biomass and demand (3). If demand will be higher than available biomass, that imports will increase.

It is well known that there are many factors able to affect biomass potential like genetically modified organisms, water availability, and climate change influence on biomass productivity (4). Also the long-term potential for energy crops is influenced by land availability, including restrictions imposed by water and nature protection, population diet, the energy crops type (species) influencing on biomass yield etc.

The Republic of Moldova, being $85 \%$ dependent on energy imports, from 2012 started to develop the appropriate legislative framework to stimulate the use of renewable energy sources. Several institutions, including the Energy Efficiency Agency and the Energy Efficiency Fund, have been created for this purpose. Most emphasis was put on the biomass, including agricultural waste, because Moldova is an agricultural country. Compare to other energy sources, the biomass can be easy converted into different states: solid, liquid and gaseous fuels (5). Additionally, bioenergy can be used for different purpose: to produce heat for homes, to produce electricity for communities and to produce fuel for transport sector. It was estimated at level of 2012 year, that bioenergy (including waste) has consti-

Table 2. Energy consumption by fuel categories in Moldova for 2010-2016.

\begin{tabular}{|l|c|c|c|c|c|c|c|}
\hline $\begin{array}{l}\text { Final energy } \\
\text { consumption, ktep }\end{array}$ & $\mathbf{2 0 1 0}$ & $\mathbf{2 0 1 1}$ & $\mathbf{2 0 1 2}$ & $\mathbf{2 0 1 3}$ & $\mathbf{2 0 1 4}$ & $\mathbf{2 0 1 5}$ & $\mathbf{2 0 1 6}$ \\
\hline Coal & 113 & 117 & 114 & 142 & 93 & 100 & 74 \\
\hline Natural gas & 456 & 447 & 421 & 390 & 386 & 393 & 418 \\
\hline Petroleum products & 722 & 762 & 701 & 720 & 740 & 778 & 840 \\
\hline Biofuel and wastes & 500 & 527 & 569 & 576 & 615 & 620 & 669 \\
\hline Electrical energy & 282 & 291 & 298 & 306 & 313 & 317 & 311 \\
\hline Thermal energy & 240 & 232 & 218 & 214 & 210 & 202 & 213 \\
\hline Total & $\mathbf{2 3 1 3}$ & $\mathbf{2 3 7 6}$ & $\mathbf{2 3 2 1}$ & $\mathbf{2 3 4 8}$ & $\mathbf{2 3 5 7}$ & $\mathbf{2 4 1 0}$ & $\mathbf{2 5 2 5}$ \\
\hline
\end{tabular}




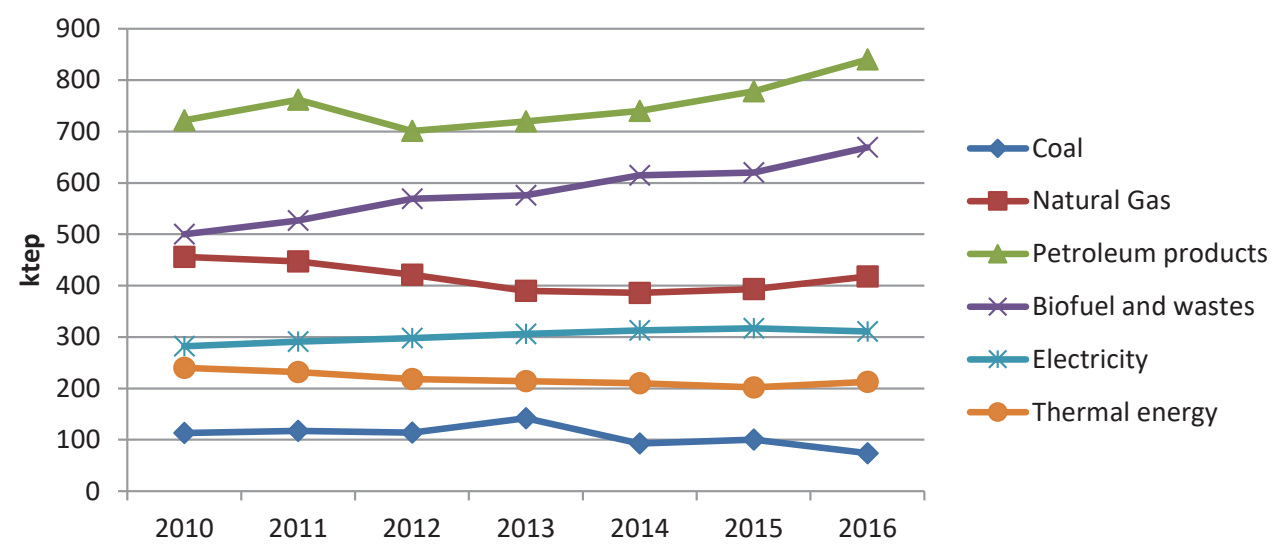

Figure 1. Energy consumption of the Republic of Moldova for the period 2010-2016 for each energy category.

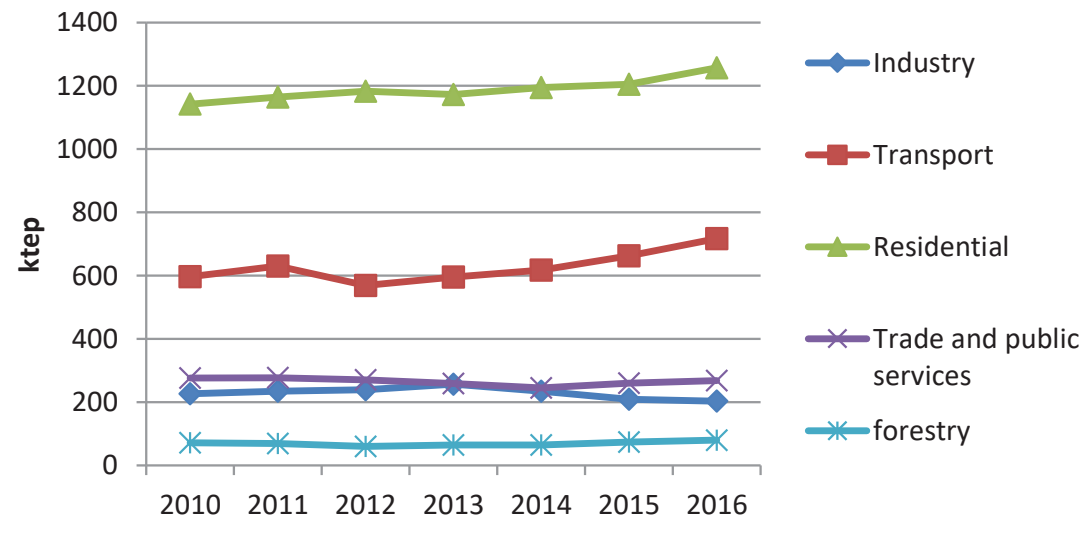

Figure 2. Energy consumption by economy sectors during period 2010-2016.

tuted $14 \%$ from world's total energy consumption (6).

Today, when all countries have a tendency to involve higher share of renewable energy sources in owns energy circuits to reduce the impact on climate change and oil extraction is no longer a priority for the financing institutions (7), the priority to extend use of renewable energy sources becomes the no. 1 for Republic of Moldova. This paper analyzes the evolution of Moldova's energy consumption and the influence of the legislative framework implemented during 2012-2016 as well as the investment projects. This analysis allows to highlight the correctness of the legislative framework, what should be done and where incentives should be applied.

\section{Moldova energy consumption}

The Republic of Moldova has an annual energy consumption of about 2300ktep. Table 2 shows the consumption of energy for each fuel category for the period 2010-2016 (7).

The energy consumption per category is presented graphically for 2010-2016 in Fig. 1.

From Fig. 1 it is evident that during the period 2000-2010 there was an increase of the petroleum products and of the category "biofuels and wastes" and the consumption of natural gas decreased. The energy consumption for each economy sector is shown in Table 3.

Table 3 and Fig. 2 show that energy consumption has started to increase most for the transport and residential sectors and the industry sector has declined slightly.

Fig. 3. shows the energy consumption for each sector of the economy in percentage terms for 2016.

From Fig. 3 it is obvious that the leader in energy consumption is the residential sector with about $50 \%$. The second place is represented by the transport sector with $28.4 \%$.

Table 3. The energy consumption by each economy sector for period 2010-2016

\begin{tabular}{|l|c|c|c|c|c|c|c|}
\hline Energy consumption, ktep & $\mathbf{2 0 1 0}$ & $\mathbf{2 0 1 1}$ & $\mathbf{2 0 1 2}$ & $\mathbf{2 0 1 3}$ & $\mathbf{2 0 1 4}$ & $\mathbf{2 0 1 5}$ & $\mathbf{2 0 1 6}$ \\
\hline Industry & 227 & 235 & 239 & 257 & 235 & 209 & 203 \\
\hline Transport & 597 & 630 & 569 & 595 & 618 & 662 & 717 \\
\hline Residential sector & 1142 & 1165 & 1183 & 1173 & 1195 & 1205 & 1257 \\
\hline Trade \& public services & 276 & 277 & 270 & 259 & 245 & 260 & 268 \\
\hline Forestry & 71 & 69 & 60 & 64 & 64 & 74 & 80 \\
\hline Total & $\mathbf{2 3 1 3}$ & $\mathbf{2 3 7 6}$ & $\mathbf{2 3 2 1}$ & $\mathbf{2 3 4 8}$ & $\mathbf{2 3 5 7}$ & $\mathbf{2 4 1 0}$ & $\mathbf{2 5 2 5}$ \\
\hline
\end{tabular}




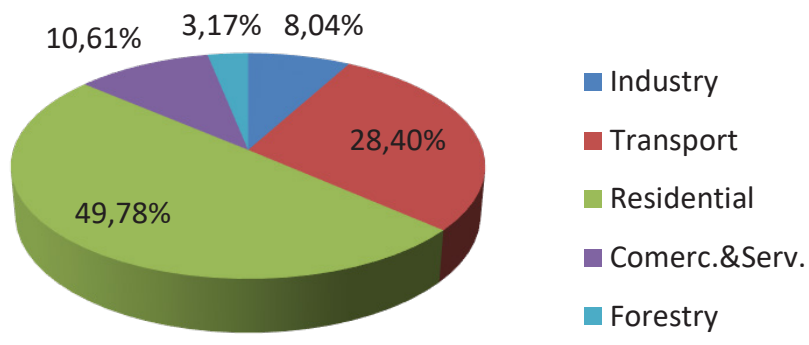

Figure 3. Energy consumption share of each economy sector in 2016.

\section{Energy policies adopted by the state}

The main strategic document in the energy sector is the Energy Strategy of Moldova until 2030 (ES-2030) adopted in 2013. The main targets included in this document are:

$\checkmark$ to reach $17 \%$ of the renewable energy in total energy consumption by 2020 ;

$\checkmark$ to reach $10 \%$ of biofuel in total fuel consumption by 2020 ;

$\checkmark$ to increase local electricity generation capacities to $800 \mathrm{MW}$ in 2020;

$\checkmark$ to produce $10 \%$ of total electricity consumption by 2020 from renewable sources;

$\checkmark$ to reduce energy intensity with $10 \%$ by 2020 ;

$\checkmark$ to reduce CO2 emissions with $25 \%$ by 2020 compared to 1990;

$\checkmark$ to install 400MW renewable electricity generation by 2020 .

In order to achieve the given strategy and align the legislation with the acquis communautaire, the Republic of Moldova has adopted and amended a number of laws in the energy sector:

$\checkmark$ Law no. 174 of 21.09.2017 on energy (this law establishes the legal framework for organizing, regulating and ensuring the efficient and secure functioning of the energy sectors);

$\checkmark$ Law no.107 of 27.05.2016 on electricity (the purpose of this law is to establish a general legal framework for the organization, regulation, ensuring efficient operation and monitoring of the power sector);

$\checkmark$ Law no.92 from 29.05.2014 regarding thermal energy and promotion of cogeneration (the main purpose of law is to establish a legal framework for the efficient operation and regulation of centralized heat supply systems and to promote the cogeneration on the basis of the useful heat demand);

$\checkmark$ Law no.107 from 27.05.2016 regarding electricity (the purpose of law is to create a framework for efficient operation and monitoring of power sector, in order to provide consumers with electricity, to ensure free electricity market access of any operators, to promote electricity production, to keep balance between production and consumption, to integrate in competitive electricity market etc.);

$\checkmark$ Law no.108 from 27.05.2016 regarding natural gas (the purpose of law is to diversify gas sources and to create opportunity for other market actors to delivery gas in the existing network);

$\checkmark$ Law no.160 from 12.07.2007 regarding renewable energy (the purpose is to create legal framework for the functioning of the renewable energy sector, the social and economic relations, the ways of organizing the production and marketing of renewable energy and fuels);

$\checkmark$ Law no.10 from 26.02.2016 regarding renewable energy and to be enforce on 25.03.2018 (the purpose is to remove barriers from law no.160 and to establish a legal framework to stimulate use of energy from renewable sources and to establish mandatory national targets for the share of RES in gross final consumption of energy and share of RES in final energy consumption in transport;

$\checkmark$ Law no. 92 of 29.05.2014 on the energy performance of buildings;

$\checkmark$ Law no.44 of 27.03.2014 on the labelling of energy-related products;

$\checkmark$ National Action Plan for Energy from Renewable Sources.

Besides the fact that the Republic of Moldova has adopted a series of legislative documents meant to stimulate the development of renewable sources and reduce greenhouse gas emissions, Parliament approved a number of agreements with external donors to stimulate efficiency projects energy and development of renewable sources. The most important donors who invested in Moldova during 2012-2017 are: World Bank, EBRD, Regional Financing - E5, EIB, Sida-EBRD Energy Efficiency Technical Co-operation Fund, GIZ, etc.

The most important projects implemented by foreign investors in Moldova, which have contributed substantially to the efficiency of the energy sector and the increase of the share of renewable sources are:

- EU Energy Budget Support pushed numerous laws and other policy reforms;

- Moldova Energy and Biomass Project;

- Energy Efficiency Fund foundation;

- Projects directly at the level of Municipalities (Green Light Moldova, REEPB, Demonstrational project for sustainable energy);

- Direct Support to interconnection with EU Energy market;

- MoSEFF \& MoREFF (Neighbourhood Investment Facility (NIF) grants with EBRD loans);

- Investment opportunities for private Sector and Residential sector;

- EU 4 Energy;

- TA Support to Modernisation of Energy Sector.

The state has also provided some tax and customs benefits to promote energy efficiency and the development of RES, including:

$\checkmark$ zero customs duty on import of photovoltaic panels;

$\checkmark$ 8\% customs duty on imports of wind farms;

$\checkmark$ VAT exemption for hydraulic turbines with a power up to $1000 \mathrm{~kW}$, electric generators with power range $75 \mathrm{~kW}$ - 
Table 4. Dependence on Moldova's energy imports during 2010-2016

\begin{tabular}{|l|c|c|c|c|c|c|c|}
\hline & 2010 & 2011 & 2012 & 2013 & 2014 & 2015 & 2016 \\
\hline Primary energy, ktep & 523 & 555 & 594 & 599 & 654 & 655 & 709 \\
\hline $\begin{array}{l}\text { Gross domestic } \\
\text { consumption, ktep }\end{array}$ & 2633 & 2676 & 2624 & 2643 & 2669 & 2686 & 2796 \\
\hline \begin{tabular}{l} 
Energy import, \% \\
\hline
\end{tabular} & 80.14 & 79.26 & 77.36 & 77.34 & 75.50 & 75.61 & 74.64 \\
\hline
\end{tabular}

\section{Energy import}

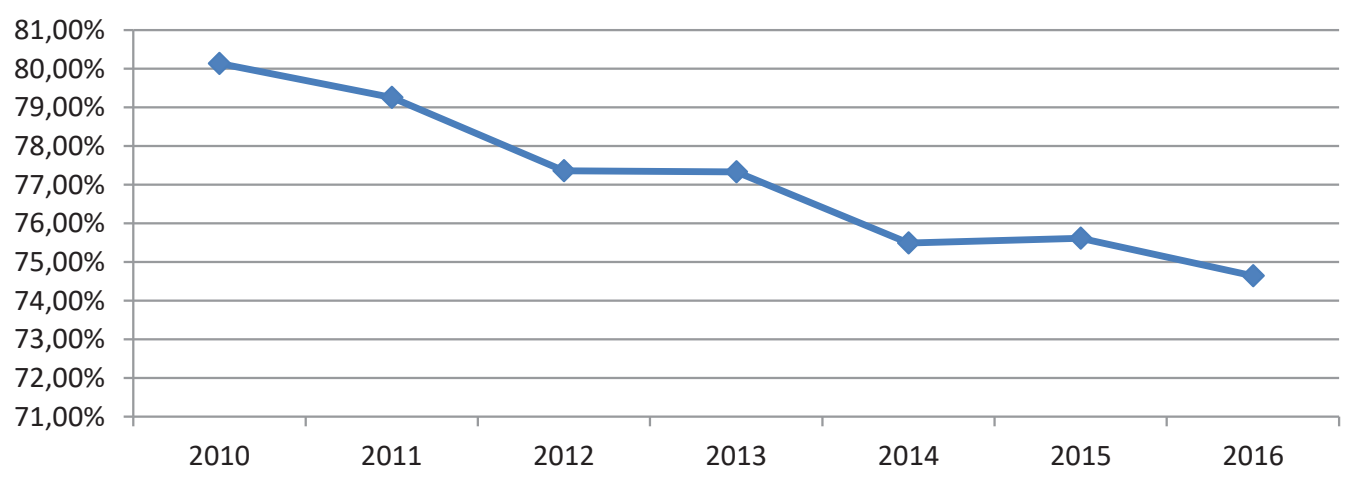

Figure 4. Energy import share of Republic Moldova during period 2010-2016

$375 \mathrm{~kW}$, parts for generating sets, etc .;

$\checkmark$ VAT exemption on construction and installation of wind and photovoltaic installations;

$\checkmark$ VAT exemption on secondary raw material, including waste and paper and cardboard, rubber, plastic and glass waste (glass fragments);

$\checkmark$ Taxation at zero rates of supplies of electricity, heating and hot water for residential real estate, irrespective of the subject in which these goods are handled and wood biomass, herbaceous plants and fruit for the production of thermal energy and hot water.

\section{Feedback of implemented energy policies}

It is very important for any country to have as little energy dependence as possible to ensure the necessary energy security. Achieving this goal requires implementing appropriate policies and securing investment in the sector. The Republic of Moldova in 2010 depended on energy imports over $80 \%$ (see Table 4).

With the implementation of the appropriate legislative framework and the introduction of incentives, local energy production began to increase and energy imports dependence began to decrease (Fig. 4).

From Fig. 4 it is evident that the energy import decreased continuously, so in 2016 it reached the level of $74.6 \%$. The biggest contribution was the increase in consumption of thermal energy produced from local sources (biomass). Fig. 5 shows the evolution of biofuel and waste consumption in 2010-2016.

The result of this increase is largely due to the implementation of few external investment projects:

a) The Energy and Biomass Project (23,97 MEuro) that is funded by the EU and implemented by the UNDP during 2011-2017. The project has a purpose to increase reliable, competitive and sustainable production of energy from biomass, that is considered the most viable and available RES in Moldova. In frame of the project 190 schools, kindergartens and community centers have installed modern biomass based heating systems and 140,000 persons benefit from securely supplied and locally produced energy. Additionally, the bioenergy production market has been developing at a rapid pace in Moldova and the components required for a smooth operation are either there already or are developing. In 2016 there were about 120 producers of solid biomass fuel with a total capacity of 120000 tons, with more than 86 thousand tons for briquettes and 33.6 thousand tons for pellets. These amounts account for almost $5 \%$ of the domestic gas consumption or $42 \%$ of the coal consumption (2). In total, the Energy and Biomass Project supported 35 biofuel startups, which created about 100 new jobs.

b) MOLDOVAN SUSTAINABLE ENERGY FINANCING FACILITY (MoSEFF) Project invested EUR 42,0 mln. during

\section{biofuel and wastes}

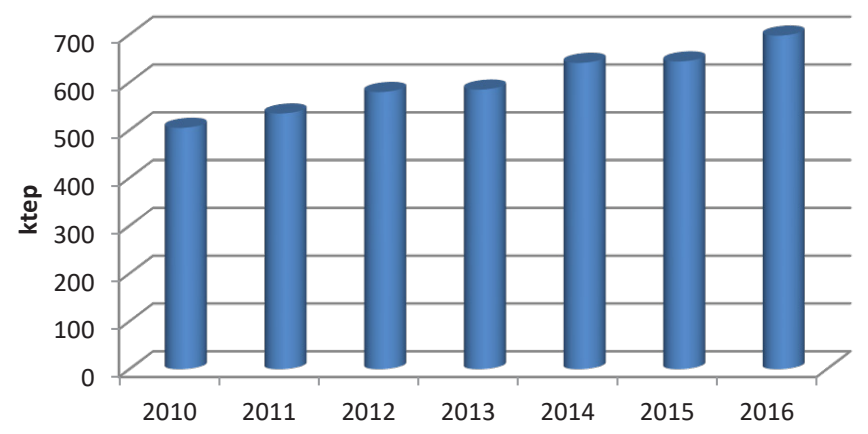

Figure 5. Evolution of energy consumption from category "biofuel and wastes" during period 2010-2016. 


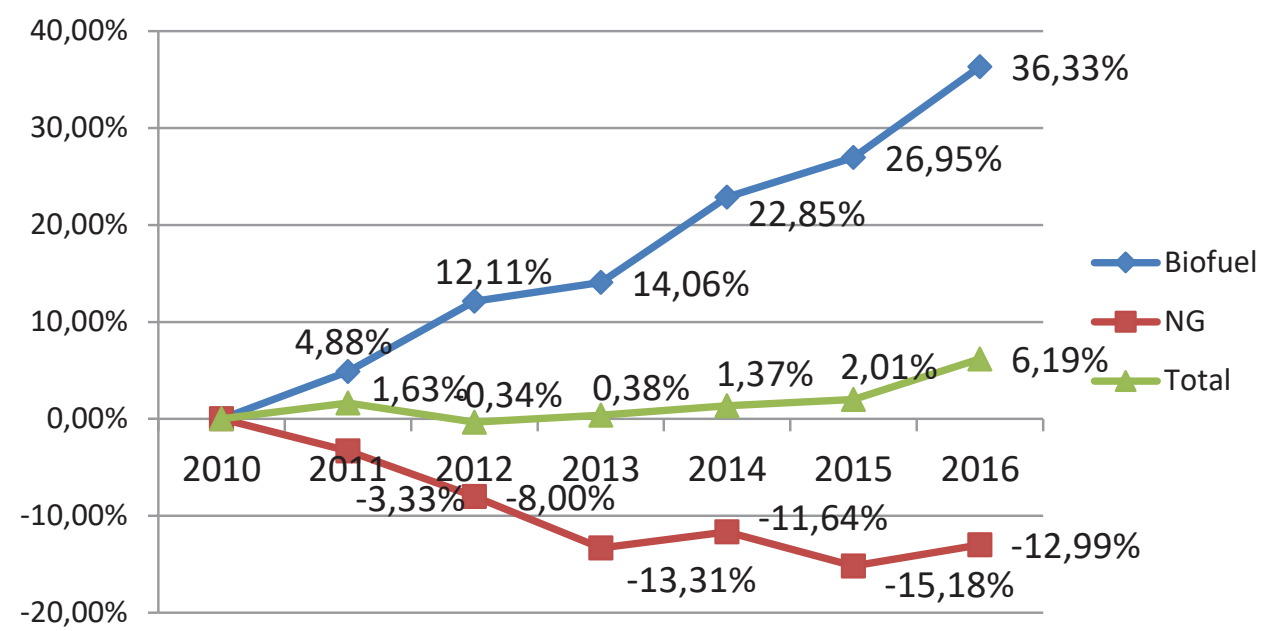

Figure 6. Evolution of natural gas and biofuel consumption, as well as total country energy consumption compared to 2010.

period 2012-2017. In total more than 260 projects on energy efficiency and renewable energy were successfully implemented. As result about 348,030MWh/yr primary energy was saved and $\mathrm{CO} 2$ reduction was $65,606 \mathrm{t}$ (3).

c) The Energy Efficiency Finance Facility in the Moldovan residential sector - 35 MEuro

d) The Eastern Europe Partnership for Energy Efficiency and Environment/E5P - 120,0 MEuro.

The beneficial influence of these investment projects is evident if we look at the evolution of energy consumption in 20102016. Fig. 6 presents the evolution of biofuel and natural gas consumption for 2010-2016 compared to 2010.

The analysis of the curves in Fig. 6 highlights the fact that since 2010 there has been a continuous increase of local energy produced in the category "biofuels and wastes", having a more pronounced increase for the period 2013-2016. In 2016, the increase in energy production in this category reached $36.33 \%$ compared to 2010. As far as the consumption of natural gas is concerned, here we have practically a continuous decrease, reaching 13\% in 2016 compared to 2010. Total consumption per country of energy has been steadily increasing over the period 2010-2016, with the exception of 2012. Between 2015 and 2016 there was a more pronounced increase in energy consumption, reaching a level of $6.2 \%$ compared to 2010 .

It is obvious that the implementation of the aforementioned projects has led to a very positive dynamics in diminishing the energy dependency. Due to the fact that a number of advanced technologies have been implemented in these projects, it has managed to maintain the increase of the total energy consumption below $6 \%$ compared to 2010 . Without the implementation of these projects, the energy consumption would have been much higher and the dependence energy would have increased.

Another beneficial component of the implementation of the relevant legislative framework is the stimulation of the development of wind and photovoltaic sources as well as of biogas installations. The capacity of the renewable sources involved in the production of electricity in 2016 is shown in Table 5.
Table 5. Capacity Electricity Installations from RES in 2016

\begin{tabular}{|l|c|}
\hline Biogas installations, kW & 2805 \\
\hline Wind installations, kW & 2335 \\
\hline Photovoltaic installations, kW & 2290.9 \\
\hline Total, kW & $\mathbf{7 4 3 0 . 9}$ \\
\hline
\end{tabular}

Today, the capacity of renewable sources of electricity generation is rising, and it is expected that after the entry into force of Law no. 10 of 2016 on the Promotion of Renewable Sources (2018), it will increase sharply. At the same time, small capacities will increase, because the new law provides for the removal of the $10 \mathrm{~kW}$ barrier to deliver energy to the grid.

Overall, the implementation of legislation aiming to stimulate energy efficiency, renewable energy sources and to create attractive conditions for investors, led to increasing in RES in Moldova's energy balance in 2015 up to $14.7 \%$ (8).

\section{References}

1. Slade R, Bauen A, Gross R. Global bioenergy resources. Nature Climate Change 2014; 4, 99-105

2. Popp J, Lakner Z, Harangi-Rákos M, Fári M. The effect of bioenergy expansion: Food, energy, and environment. Renewable and Sustainable Energy Reviews 2014; 32559-578 1364-0321

3. Importance Of Bioenergy Should Not Be Underestimated (http:// www.theglobaljournal.net/group/global-minds/article/1124/

4. Bioenergy. Strategic Insight. World Energy Resources: Bioenergy World Energy Council 2013, https://www.worldenergy.org/

5. World Energy Resources Bioenergy | 2016, World Energy Council. https:/www.worldenergy.org/

6. World Bank Group Announcements at One Planet Summit, PRESS RELEASE NO: 2018/087/CCG, HTTP://WWW.WORLDBANK.ORG/ EN/NEWS/PRESS-RELEASE/2017/12/12/WORLD-BANK-GROUPANNOUNCEMENTS-AT-ONE-PLANET-SUMMIT

7. National Bureau of Statistics. http://www.statistica.md/

8. http://ecopresa.md/producerea-de-energie-regenerabila-in-moldova/

9. National inventory report 1990-2015. www.clima.md. 